\title{
Invasive Plants in the Coastal Vegetal Communities in Valencia (Spain)
}

\author{
Francisco FERRER MERINO, Pilar M. DONAT \\ Universidad Politécnica de Valencia, EPS Gandia, Dto. Ecosistemas Agroforestales. Carretera \\ Nazaret-Olivas/n, 46730, Gandia, Spain; mpdonat@eaf.upv.es
}

\begin{abstract}
A botanical survey has been conducted to determine the influence of invasive species on the main indigenous communities in the Spanish Mediterranean coast and evaluate the current status of these communities in the eastern coast of Spain. The work was done in about $35 \mathrm{~km}$ of coastline located in Valencia (Spain). A total of 361 species cataloged are present in the study area, belonging to 79 different families. 49 of them have been inventoried invasive species which currently affect 38 plant communities. For this cause, we have developed a map of location finding out the area occupied by the same at every point and key to indigenous communities it affects. The plant communities characteristic of semi-mobile dunes Centaureo maritimae-Echietum sabulicolae and Medicagini marinaeAmmophiletum australis have turned out to have a greater degree of invasion. Carpobrotus edulis, Agave americana, Arundo donax, Oxalis pes-caprae and Cortaderia sellowiana are invasive species that cause further encroachment, both in area as a number of vegetation communities they affect.
\end{abstract}

Keywords: coastal vegetation, dunes, habitat directive, invasive plants, Valencian vegetation

\section{Introduction}

The colonisation of invasive alien plants in the coastal ecosystems is one of the causes of the native flora population decline (Vilá, 2008). In the Mediterranean coast of Valencia has long been found species with an invasive behaviour, and many studies have been carried out on some of them, with control actions over their population as well (Silveira et al., 2010). But the existence of many other invasive species has been detected, which could be significantly affecting the coastal vegetation (Chamarro et al., 2010).

The aim of this study is to evaluate the degree of invasion of the natural coastal ecosystems and the impact they are supporting on them, to take appropriate conservation measures. The main hypothesis is that the qualitative and quantitative presence of invasive plants is bigger than the detected until now and could have negative influences to all coastal plant communities.

The study area is a Mediterranean coastal strip located in Valencia (SE Spain). This area is located between the mouths of Jucar river, on the north (UTM European Datum: Time 30S 738548.4337493) and Racons river, on the south (757286.4308407). Its length is $33 \mathrm{Km}$ and has an average width of $47.6 \mathrm{~m}$. This is a mostly a coastline of sandy sediment in which the width dunes were only interrupted by mouths of rivers and channels (Costa, 1999).

Natural dune areas are now between large urban centres. Inland, behind the dunes and farther from the sea, there are some wetlands, valuable remnants of the vast marsh that existed north and south of the territory.
The study area is protected by European, national and local legislation.

In the study area there are several SCIs (Sites of Community Importance included in Natura 2000 network). One SCI includes the coastal dunes of la Safor, other two the mouths of rivers Jucar and Racons, and the forth an adjacent wetland ("Marsh of La Safor").

-The local legislation level is the "Catalogue of Wetlands", in which are included the mouths of these rivers and several wetlands of the area or close to it.

- The national legislation level is the Spanish Coastal Law, to protect the sea shore, dunes and adjacent wetlands.

Regarding the bioclimatic features, the thermotype presented in this area is Superior Thermomediterranean with an Inferior Subhumid ombrotype (Rivas-Martínez, 2008).

\section{Material and methods}

At first, in the study the flora of the coastal habitats and the plant communities have been catalogued and inventoried, identifying associations that are ascribed to habitats of the Habitats Directive of the European Union. The invasive species also have been incorporated into the catalogue. Secondly, it has been realised a detail study of 28 invasive species. All located individuals have been mapped and their area has been estimated. The invasive species of the same genus which are demonstrating a similar behaviour regarding to the invasion of communities of vegetation have been classified as genus. 
10

The field work was carried out during two years, visiting the area regularly, covering entirely the coast in different seasons of the year. The location of different taxa was carried out, using GPS, orthophotos and maps of the area, and with these data a geodatabase using Arc GIS programs for Windows V.3.2 has been done.

The specific definition of the study area was carried out following the location of vascular plants from the shore line to the first human constructions, as promenades and buildings, if they exist in front of the beach. In the absence of these constructions, the inventory reached few meters behind the dunes. This covers a study area between 10 and $150 \mathrm{~m}$ wide.

The development of floristic list is based on the in situ identification of the taxa and, exceptionally, their collection for subsequent determination. The voucher specimens are preserved in the GAN Herbarium of the Polytechnic University of Valencia (UPV).

For the identification and nomenclature of taxa the following criteria have been followed: Mateo and Crespo (2009), "Flora Ibérica” (Castroviejo et al., 1986-2010), "Flora Europaea" (Tutin et al., 1964-1980, 2002) and the "Flora Ornamental Española" (Spanish Ornamental Plants) for invasive species (López Lillo et al., 2007).

To study the vegetation the phytosociological method of school Braun-Blanquet (1979) has been followed, updated according to specific studies in the area (Soriano, 1995; Ferrer, 2008; Lourbe, 2006; Silveira et al., 2010; Chamarro et al., 2010).

The plant communities are classified in asyntaxonomical scheme according to the "Checklist of vascular plants Syntaxonomical Communities" by Rivas-Martínez et al. (2001 and 2002). The numbers listed before taxonomic categories correspond to the numbers that have these categories in the Syntaxonomical Checklist (RivasMartínez et al., op. cit.).

To determine whether the plant communities found can be included in the Habitats Directive Interpretation Manual (European Commission, 2007), specific publications (Bartolomé et al., 2005) have been used.

A species was considered as invasive in the area when following behaviour was detected:

- in less than 50 years it has established $100 \mathrm{~m}$ away from the input focus in case of plants that reproduces by seeds.

- in less than three years it has spread at more than $6 \mathrm{~m}$ away from the input focus, if its reproduction is vegetative through rhizomes or stolons (Vilà et al., 2008).

In the absence of data the Atlas of invasive alien plants Spain (Sanz et al., 2004) has been followed.

Several invasive species were not included in the present study, since their presence in the area was nor confirmed, although there are literature references about their location near the study area.

\section{Results and discussion}

\section{Synthesis of flora and vegetation}

\section{Taxonomic analysis}

A total of 361 species from 79 families were identified in the area of study. Most of the species are dicots (289), and only few are pteridophytes (2) and gymnosperms (1).

The three most represented families are Compositae $(55$ species), Gramineae (48), and Leguminosae (22).

Other well represented families after they are Euphorbiaceae (15), Umbelliferae (13), Brassicaceae (11), Caryophyllaceae (10), Labiatae (9) and Chenopodiaceae (9).

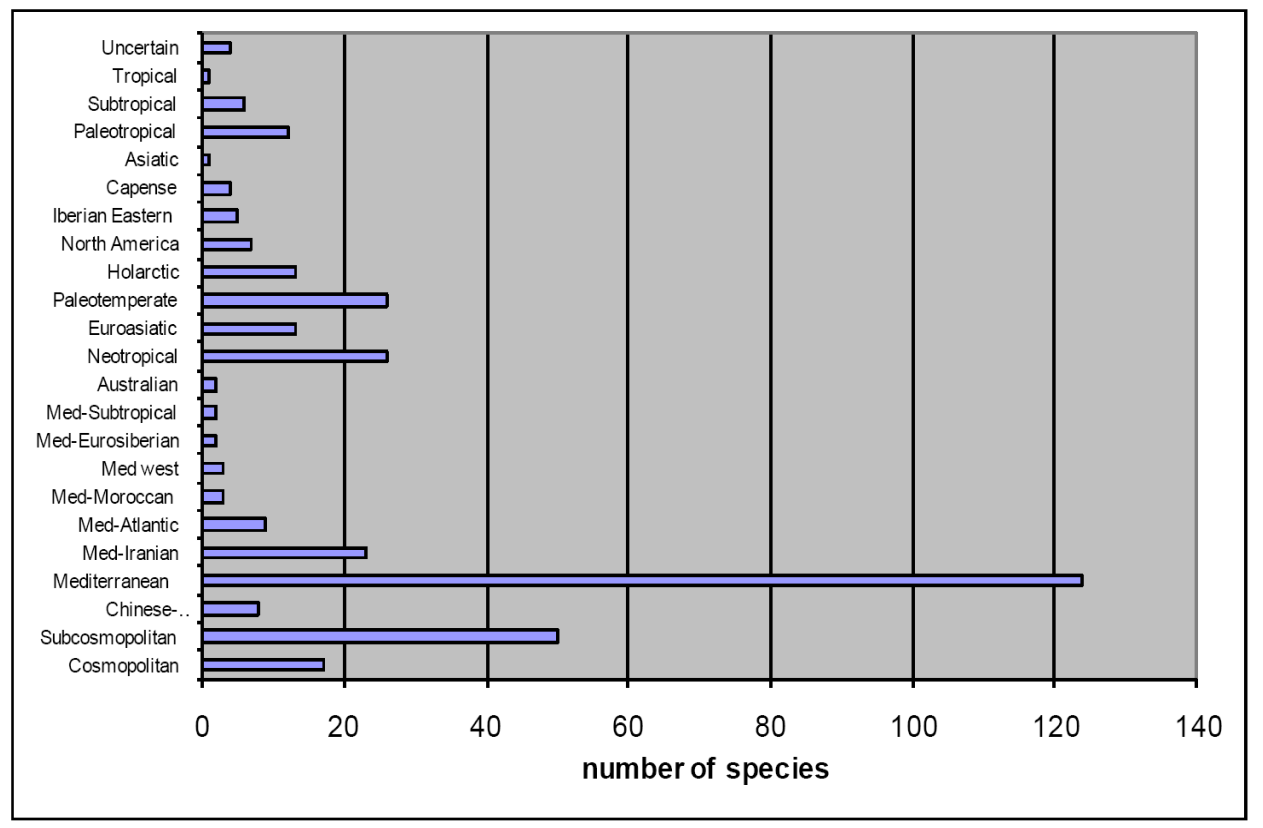

Fig. 1. Distribution of species 
Analysis of biotypes

According to the classification of biological forms by Raunkjaer (1934), we have found 128 therophytes, 90 hemicryptophytes, 35 chamaephytes, 48 phanerophytes, 49 geophytes and 12 water plants. It is worth noting the large number of therophytes, maybe due to ornamental and landscaping gardening.

\section{Analysis of habitat preference}

Ruderal environments represent the preferred habitat for the species, and urban roads are significant (52\%). These areas are subject to strong human influence.

Also noteworthy is the presence of preference for agroecosystems but with a lesser extent (12\%). These ecosystems remain influenced by human being.

As the area of the study is a coastal zone, a large number of species found have a coastal character and live in areas of beach, dunes and coastal wetlands (25\%). These habitats are natural ecosystems although they are strongly influenced by human activity. The riparian environment would be in the same case, where there is a significant representation of species.

\section{Biogeographical distribution analysis}

Most of the species found are Mediterranean, 124 species of the 361 scheduled. The diverse origin of the different species found is due to the introduction of exotic species. Among these we should mention the good representation of species with tropical origin (about 44 species). It is also important the number of paleotemperates found, 26 of 361 . The number of endemic species is relatively low, occurring only 5 species.

\section{Habitats of Network Natura 2000}

The list below shows the habitats included in the Habitats Directive found in the territory, both in areas which now have some specific global protection (SCIs, local protected sites) and outside these areas. The priority habitats are marked with an asterisk.

Malcolmietalia dune grasslands. Code: 2230 Association: Erodio laciniati-Maresietum nanae

Crucianellion maritimae fixed beach dunes. Code: 2210 Association: Medicagini-Ammophiletum australis

Embryonic shifting dunes. Code: 2110 Association: Eryngio maritimi-Sporoboletum arenarii Association: Cypero mucronati-Agropyretum juncei

Thermomediterranean riparian galleries and thickets Code: $92 \mathrm{DO}$

Association: Tamaricetum gallicae

Natural eutrophic lakes with Magnopotamion or $\mathrm{Hy}$ drocharition vegetation Code: 3150

Association: Lemnetum gibbae

${ }^{*}$ Coastal lagoons. Code 1150

Association: Typho domingensis-Phragmitetum maximi
Mediterranean and thermo-Atlantic halophilous scrubs (Sarcocornetea fruticosi). Code: 1420

Association: Statico bellidifoliae-Salicornietum fruticosae

Mediterranean salt meadows (Juncetalia maritimi). Code: 1410

Association: Elymo elongati-Juncetum maritimi

Association: Schoeno nigricantis-Plantaginetum crassifoliae

Mediterranean tall humid herb grasslands of the Molinio-Holoschoenion. Code: 6420

Association: Holoschoenetum vulgaris

Constantly flowing Mediterranean rivers with PaspaloAgrostidion species and hanging curtains of Salix and Populus alba. Code: 3280

Association: Paspalo distichi-Agrostietum verticillatae

${ }^{*}$ Calcareous fens with Cladium mariscus and species of the Caricion davallianae. Code: 7210. Prioritary habitat.

Association: Hydrocotylo-Mariscetum serrati

Annual vegetation of drift lines. Code: 1210

Association: Salsolo kali-Cakiletum aegyptiacae

Perennial vegetation of stony banks. Code: 1220

Association: Hypochoerido radicatae-Glaucietum flavi

\section{Vegetation}

The study area was previously dominated by Mediterranean coastal dunes, which have occupied these decreasing surface area.

The few dunes that lie along the study area have yet part of the biodiversity of flora and fauna that characterize these ecosystems. This is because they represent the interface between the marine habitat and inlands, in which we can find species of great variability and even adapted to extreme conditions of insolation, salinity and other aggressions that present the coastal ecosystem.

An amount of 38 associations and plant communities have been recorded, included in 17 vegetation classes. Of these, 10 are from dune communities, 2 from rocky shore communities or gravel, 11 from coastal and riparian wetlands, 1 from shrub and 14 from weedy and greens communities that are replacing the previous.

\section{Syntaxonomical scheme}

12-CL: Phragmito-Magnocaricetea Klika in Klika and Novák 1941

12a. Phragmitetalia Koch 1926

12.1. Phragmition communis Koch 1926

Association: 12.1.4. Typho domingensis-Phragmitetum maximi Costa, Boira, Peris and

Stübing 1986 corr. Rivas-Martínez, FernándezGonzález, Loidi, Lousã and Penas 2002.

16.-CL: Ammophiletea Br.-Bl. and Tüxen ex Westhoff, Dijk and Passchier 1946

16a. Ammophiletalia Br.-Bl. 1933 
12

16.1. Ammophilion australis Br.-Bl. 1921 corr. RivasMartínez, Costa and Izco in Rivas-Martínez, Lousã, Díaz, Fernández-González and Costa 1990.

16.1a. Ammophilenion australis

Association: 16.1.2. Medicagini marinae-Ammophiletum australis Br.-Bl. 1921 corr. F. Prieto and E. Díaz 1991.

16.2. Agropyro-Minuartion peploidis Tüxen in Br.-Bl. and Tüxen 1952

16.2b. Agropyrenion farcti Rivas-Martínez, Costa, Castroviejo and E. Valdés 1980

Association: 16.2.2. Cypero mucronati-Elytrigietum juncei Kühnholtz ex Br.-Bl. 1933 nom. mut. prop.

16.3. Sporobolion arenarii (Géhu and Géhu-Franck ex Géhu and Biondi 1994) Rivas-Martínez, FernándezGonzález, Loidi, Lousã and Penas 2002.

Association: 16.3.1. Eryngio maritimi-Sporoboletum arenarii (Arènes ex Géhu and Biondi 1994) Rivas-Martínez, Fernández-González, Loidi, Lousã and Penas 2002.

16b. Crucianelletalia maritimae Sissingh 1974

16.4. Crucianellion maritimae Rivas Goday and RivasMartínez 1958

Association: 16.4.2. Loto cretici-Crucianelletum maritimae Alcaraz, T.E. Díaz, Rivas Martínez and P. Sánchez 1989

17.-CL: Cakiletea maritimae Tüxen and Preising ex Br.-Bl. and Tüxen 1952

17a. Cakiletalia integrifoliae Tüxen ex Oberdorfer 1949 corr. Rivas-Martínez, Costa and Loidi 1992

17.2. Cakilion maritimae Pignatti 1953

Association: 17.2.3. Hypochoerido radicatae-Glaucietum flavi Rivas Goday and Rivas-Martínez 1958

Association: 17.2.4. Salsolo kali-Cakiletum aegyptiacae Costa and Mansanet 1981

19.-CL: Crithmo-Staticetea Br.-Bl. in Br.-Bl., Roussine and Nègre 1952

19a. Crithmo-Staticetalia Molinier 1934

19.1. Crithmo-Staticion Molinier 1934

19.1a. Crithmo-Staticenion

Association: 19.1.2. Crithmo-Helichrysetum decumbentis Rigual 1972

20.-CL: Juncetea maritimi Br.-Bl. in Br.-Bl., Roussine and Nègre 1952

20a. Juncetalia maritimi Roussine and Nègre 1952

20.1. Juncion maritimi Roussine and Nègre 1952

20.1a. Juncenion maritimi

Association: 20.1.2. Elymo elongati-Juncetum maritimi Alcaraz, Garre, Peinado and Martínez-Parras 1986

20.2. Plantaginion crassifoliae $\mathrm{Br}$--Bl. in $\mathrm{Br}$.-Bl., Roussine and Nègre 1952

Association: 20.2.2. Schoeno nigricantis-Plantaginetum crassifoliae Br.-Bl. in Br.-Bl., Roussine and Nègre
22.-CL: Saginetea maritimae Westhoff, Van Leeuwen and Adriani 1962

22b. Frankenietalia pulverulentae Rivas-Martínez ex Castroviejo and Porta 1976

22.2. Frankenion pulverulentae Rivas-Martínez ex Castroviejo and Porta 1976

Association: 22.2.5. Parapholido incurvae-Catapodietum marini Rivas-Martínez, Lousã, T.E. Díaz, FernándezGonzález and J.C. Costa 1990

23.-CL: Sarcocornietea fruticosae Br.-Bl. and Tüxen ex A. and O. Bolòs 1950 nom. mut. propos.

23a. Sarcocornietalia fruticosae Br.-Bl. 1933 nom. mut. propos.

23.1. Sarcocornion fruticosae Br.-Bl. 1933 nom. mut. propos.

23.1a. Sarcocornienion fruticosae Rivas-Martínez and Costa 1984 nom. mut. propos.

Association: 23.1.4. Statico bellidifoliae-Sarcocornietum fruticosae Br.-Bl. 1933 nom. mut. propos.

23b. Limonietalia Br.-Bl. and O. Bolòs 1958

Limonium community

28.-CL: Parietarietea Rivas-Martínez in Rivas Goday 1964

28a. Parietarietalia (Rivas-Martínez 1960) Rivas Goday 1964

28.1. Parietario judaicae-Centranthion rubri RivasMartínez 1960

Association: 28.1.9. Parietarietum judaicae K. Buchwald 1952

34.-CL: Artemisietea vulgaris Lohmeyer, Preising and Tüxen ex von Rochow 1951

34a. Artemisienea vulgaris

34b. Agropyretalia repentis Oberdorfer, Müller and Görs in Oberdorfer, Görs, Korneck, Lohmeyer, Müller, Philippi and Seibert 1967

34.6. Bromo-Oryzopsion miliaceae O. Bolòs 1970

Association: 34.6.2. Centaureo maritimae-Echietum sabulicolae Costa and Mansanet 1981

Association: 34.6.6. Inulo viscosae-Oryzopsietum miliaceae O. Bolòs 1957 1975

38.-CL: Polygono-Poetea annuae Rivas-Martínez

38a. Polygono arenastri-Poetalia annuae Tüxen in Géhu, Richard and Tüxen 1972 corr. Rivas-Martínez, Báscones, T.E. Díaz, Fernández-González and Loidi 1991

38.5. Euphorbion prostratae Rivas-Martínez 1976

Association: 38.5.1. Euphorbietum chamaesyco-prostratae Rivas-Martínez 1976

39.-CL: Stellarietea mediae Tüxen, Lohmeyer and Preising ex von Rochow 1951 
39c. Solano nigri-Polygonetalia convolvuli (Sissingh in Westhoff, Dijk and Passchier 1946) O. Bolòs 1962

39.6. Diplotaxion erucoidis Br.-Bl. in Br.-Bl., Gajewski, Wraber and Walas 1936

Association: 39.6.1. Amarantho delilei-Diplotaxietum erucoidis Br.-Bl. in Br.-Bl., Gajewski, Wraber and Walas 1936

39.7. Fumarion wirtgenii-agrariae Brullo in Brullo and Marcenò 1985

Association: 39.7.2. Citro-Oxalidetum pedis-caprae O. Bolòs 1975

39b. Chenopodio-Stellarienea Rivas Goday 1956

39d. Chenopodietalia muralis Br.-Bl. in Br.-Bl., Gajewski, Wraber and Walas $1936 \mathrm{em}$. Rivas-Martínez 1977

39.8c. Malvenion parviflorae Rivas-Martínez 1978

Association: 39.8.12. Emici spinosae-Malvetum parviflorae Rivas-Martínez in Rivas-Martínez, Costa, Castroviejo and E. Valdés 1980

Association: 39.8.18. Sisymbrio irionis-Lavateretum creticae (Mateo and M.B. Crespo 1988) Carretero and Aguilella 1995

39f. Sisymbrietalia officinalis J. Tüxen in Lohmeyer and al. 1962 em. Rivas-Martínez, Báscones, T.E. Díaz, Fernández-González and Loidi 1991

39.16. Hordeion leporini Br.-Bl. in Br.-Bl., Gajewski, Wraber and Walas 1936 corr. O. Bolòs 1962

Association: 39.16.2. Asphodelo fistulosi-Hordeetum leporini A. and O. Bolòs in O. Bolòs 1956

40.-CL: Galio-Urticetea Passarge ex Kopecký 1969

40b. Calystegietalia sepium Tüxen ex Mucina 1993 nom. mut. propos.

40.5. Calystegion sepium Tüxen ex Oberdorfer 1957 nom. mut. propos.

Association: 40.5.2. Arundini donacis-Convolvuletum sepium Tüxen and Oberdorfer ex O. Bolòs 1962

Association: 40.5.4. Ipomoeo sagittatae-Cynanchetum acuti Costa, Boira, Peris and Stübing 1986

Association: 40.5.3. Cyrsio ferocis-Epilobietum hirsuti O. Bolòs 1996 corr. Rivas- Martínez, T.E. Díaz, Fernández-González, Loidi, Lousã and Penas 2002

50.-CL: Helianthemetea guttati (Br.-Bl. in $\mathrm{Br}$-- $\mathrm{Bl}$., Roussine and Nègre 1952) Rivas Goday and Rivas-Martínez 1963 em. Rivas-Martínez 1978

50b. Cutandietalia maritimae Rivas-Martínez, DíezGarretas and Asensi in Rivas-Martínez et al. 2002

50.7. Alkanno-Maresion nanae Rivas Goday ex Rivas Goday and Rivas-Martínez 1963 Díez-Garretas, Asensi and Rivas-Martínez 2001

Association: 50.7.3. Erodio laciniati-Maresietum nanae Rivas Goday 1958 corr. Costa, Díez-Garretas, P. Soriano and Pérez-Badia in Pérez-Badia 1997

56-CL: Lygeo-Stipetea Rivas-Martínez 1978

56b. Hyparrhenietalia hirtae Rivas-Martínez 1978
56.7. Hyparrhenion hirtae Br.-Bl., P. Silva and Rozeira 1956

Association: 56.7.1. Aristido coerulescentis-Hyparrenietum sinaicae Rivas-Martínez and Alcaraz in Alcaraz 1984 nom. mut. propos.

59.-CL: Molinio-Arrhenatheretea Tüxen 1937

59c. Holoschoenetalia vulgaris Br.-Bl. ex Tchou 1948

59.7. Molinio-Holoschoenion vulgaris $\mathrm{Br}$ - $\mathrm{Bl}$. ex Tchou 1948

Association: 59.7.11. Holoschoenetum vulgaris $\mathrm{Br}$--Bl. ex Tchou 1948

59d. Paspalo-Heleochloetalia Br.-Bl. in Br.-Bl., Roussine and Nègre 1952

59.10. Paspalo-Agrostion verticillati $\mathrm{Br}$ - $\mathrm{Bl}$. in $\mathrm{Br}$-- $\mathrm{Bl}$., Roussine and Nègre 1952

Association 59.10.2. Cyperetum distachyi $\mathrm{O}$. Bolòs and Molinier 1984

Association 59.10.6. Paspalo-Polygonion viridis $\mathrm{Br}$-- $\mathrm{Bl}$. in Br.-Bl., Roussine and Nègre 1952 nom mut. propos.

59e. Plantaginetalia majoris Tüxen and Preising in Tüxen 1950

59.11. Potentillion anserinae Tüxen 1947

Association 59.11.2. Lolio perennis-Plantaginetum majoris Beger 1930

59.12. Trifolio fragiferi-Cynodontion $\mathrm{Br}-\mathrm{Bl}$. and $\mathrm{O}$. Bolòs 1958

Association: 59.12.7. Potentillo reptantis-Agrostietum stoloniferae O. Bolòs in O. Bolòs and Molinier 1984

Association: 59.12.8. Trifolio fragiferi-Cynodontetum dactyli Br.-Bl. and O. Bolòs 1958

Association: 59.12.7. Potentillo reptantis-Agrostietum stoloniferae O. Bolòs in O. Bolòs and Molinier 1984

Association: 59.15.8. Potentillo reptantis-Menthetum suaveolentis Oberdorfer 1952

70.-CL: Nerio-Tamaricetea Br.-Bl. and O. Bolòs 1958

70a. Tamaricetalia Br.-Bl. and O. Bolòs $1958 \mathrm{em}$. Izco, Fernández-González and A. Molina 1984

70.1. Tamaricion africanae $\mathrm{Br}$.-Bl. and O. Bolòs 1958

Association:70.1.3. Tamaricetum gallicae Br.-Bl. and O. Bolòs 1958

70.2. Imperato cylindricae-Sacharion ravennae $\mathrm{Br}$--Bl. and O. Bolòs 1958 nom. mut. propos.

Association: 70.2.1. Equiseto ramosissimi-Erianthetum ravennae $\mathrm{Br}$ - $\mathrm{Bl}$. and $\mathrm{O}$. Bolòs 1958

71.-CL: Salici purpureae-populetea Nigrae (RivasMartínez and Cantó ex Rivas-Martínez Báscones, T.E. Díaz, Fernández-González and Loidi) classis nova

71a. Populetalia albae Br.-Bl. ex Tchou 1948

71.2. Populion albae Br.-Bl. ex Tchou 1948

71.2a. Populenion albae

Association: 71.2.9. Vinco-Populetum albae (O. Bolòs and Molinier 1958) O. Bolòs 1962

71b. Salicetalia purpureae Moor 1958 
14

71.6. Salicion discolori-neotrichae $\mathrm{Br}$-Bl. and O. Bolòs 1958 corr. Rivas-Martínez, T.E. Díaz, Fernández-Gonzalez, Izco, Loidi, Lousã and Penas

Association: 71.6.1. Salicetum discoloro-angustifoliae Rivas-Martínez ex G. López 1976 Alcaraz, P. Sánchez, De la Torre, Ríos and J. Alvarez 1991

75.-CL: Quercetea ilicis Br.-Bl. ex A. and O. Bolòs 1950

75b. Pistacio lentisci-Rhamnetalia alaterni Rivas-Martínez 1975

75.5. Asparago albi-Rhamnion oleoidis Rivas Goday ex Rivas-Martínez 1975

Association: 75.5.13. Phillyreo angustifoliae-Rhamnetum angustifoliae Costa and Mansanet 1981

\section{Invasive species}

In the study 49 invasive species have been catalogued:

Agave americana $\mathrm{L}$. Prain.

Agave sisalana (Engelm.) Perrine ex J.R. Drumm and

Aloë arborescens Mill.

Amaranthus retroflexus $\mathrm{L}$.

Amaranthus blitoides S. Watson

Aptenia cordifolia (L. fil.) Schwantes

Arctotheca calendula (L.) Levyns

Arundo donax L.

Aster squamatus (Spreng.) Hieron

Canna indica L.

Carpobrotus acinaciformis (L.) L. Bolus

Chrysanthemoides monilifera (L.) Norl.

Carpobrotus edulis (L.) N.E.Bs.

Conyza bonariensis (L.) Cronq.

Conyza canadensis (L.) Cronq.

Cortaderia selloana Ach and Graebn.
Crassula ovata (Mill.) Druce

Cylindropuntia subulata (Muehlenpfordt) Backeberg

Disphyma crassifolia (L.) L. Bolus

Drosanthemum floribundum Schwantes.

Ficus elastica Roxb. ex Hornem

Gazania rigens (L.) Gaertner

Heliotropium curassavicum L.

Ipomoea indica (Burm.) Merr.

Ipomoea sagittata Poir.

Kalanchoe blossfeldiana CV.

Lantana camara L.

Ligustrum ovalifolium Hassk.

Lonicera japonica Thunb.

Myoporum laetum $\mathrm{G}$. Forst.

Nicotiana glauca R. C. Graham

Opuntia dillenii (Ker-gawler) Haw.

Opuntia maxima Miller .

Oxalis pes-caprae $\mathrm{L}$.

Paspalum distichum $\mathrm{L}$.

Pelargonium spp.

Pennisetum clandestinum Chiov.

Pittosporum tobira (Thunb.) W. T.Aiton

Populus $x$ canadensis Moench

Ricinus communis $\mathrm{L}$.

Senecio cineraria DC.

Senecio mikanioides Otto ex Walp

Solanum nigrum L.

Sorghum halepense (L.) Pers.

Stenotaphrum secundatum (Walter) O.Kuntze

Washingtonia filifera (Lindren ex André) $\mathrm{H}$. Wendl.

Washingtonia robusta $\mathrm{H}$. Wendl.

Xanthium italicum Moretti

Yucca aloifolia L.

Yucca gloriosa L.

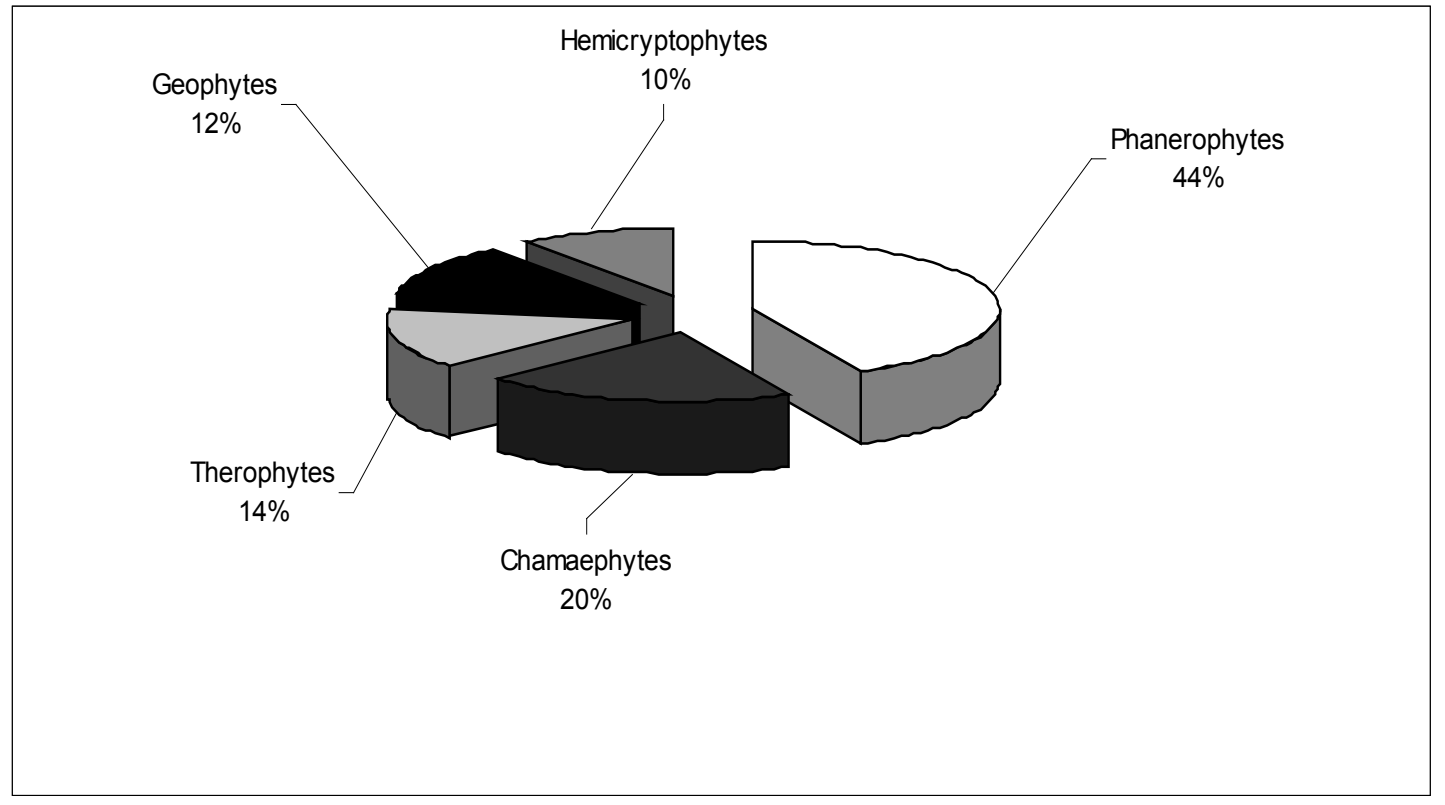

Fig. 2. Invasive species biotypes 
Tab. 1. Invasive area location of invasive species and xenotypes

\begin{tabular}{|c|c|c|c|c|}
\hline Invasive species & Invasive area $\left(\mathrm{m}^{2}\right)$ & Numb. loc. & Numb assoc. & Xenotype \\
\hline Agave spp. & 7,033 & 13 & 20 & metaphyte hemiagriophyte \\
\hline Aloe arborescens & 286 & 59 & 8 & diaphyte ergasiofigophyte \\
\hline Aptenia cordifolia & 59 & 6 & 8 & metaphyte holoagriophyte \\
\hline Arctotheca calendula & 53 & 8 & 7 & metaphyte hemiagriophyte \\
\hline Arundo donax & 22.970 & 128 & 19 & metaphyte epecophyte / hemiagriophyte \\
\hline Aster spp. & 3 & 1 & 6 & metaphyte epecophyte / hemiagriophyte \\
\hline Carpobrotus edulis & 29,491 & 348 & 21 & metaphyte holoagriophyte \\
\hline Cortaderia selloana & 231 & 14 & 15 & metaphyte hemiagriophyte \\
\hline Cylindropuntia ebulata & 7 & 3 & 6 & metaphyte hemiagriophyte \\
\hline Disphyma crassifolia & 3 & 2 & 9 & metaphyte holoagriophyte \\
\hline Drosanthemum floribundum & 130 & 10 & 9 & metaphyte holoagriophyte \\
\hline Gazania rigens & 431 & 9 & 9 & metaphyte holoagriophyte \\
\hline Ipomoea acuminata & 110 & 2 & 8 & metaphyte epecophyte \\
\hline Kalanchoe blossfeldiana & 2 & 2 & 4 & diaphyte \\
\hline Lonicera japonica & 2 & 1 & 3 & metaphyte hemiagriophyte \\
\hline Myoporum laetum & 15 & 1 & 3 & metaphyte epecophyte \\
\hline Nicotiana glauca & 6 & 2 & 18 & metaphyte holoagriophyte \\
\hline Opuntia spp. & 402 & 41 & 17 & metaphyte hemiagriophyte \\
\hline Oxalis pes-caprae & 170 & 13 & 15 & metaphyte epecophyte/ hemiagriophyte \\
\hline Pelargonium spp. & 1 & 1 & 4 & metaphyte epecophyte \\
\hline Pittosporum tobira & 47 & 11 & 4 & diaphyte ergasiophyte \\
\hline Populus $x$ canadiensis & 5 & 1 & 2 & metaphyte hemiagriophyte \\
\hline Ricinus communis & 5 & 3 & 13 & metaphyte epecophyte \\
\hline Senecio cineraria & 28 & 3 & 3 & metaphyte holoagriophyte \\
\hline Senecio mikanoides & 61 & 3 & 3 & metaphyte hemiagriophyte \\
\hline Stenotaphrum secundatum & 5 & 1 & 7 & metaphyte hemiagriophyte \\
\hline Whasingtonia spp. & 30 & 4 & 1 & diaphyte ergasiophyte \\
\hline Yucca spp. & 1,868 & 117 & 19 & diaphyte ergasiophyte \\
\hline
\end{tabular}

The following figure shows the percentage of each biotype according to the classification of biological forms from Raunkjaer (1934).

Another factor taken into account is the origin of each invasive, as it is shown in Fig. 3:
Most of the exotic species found have an American or African origin. In this second case, most of them comes from South Africa. It is also important the large number of
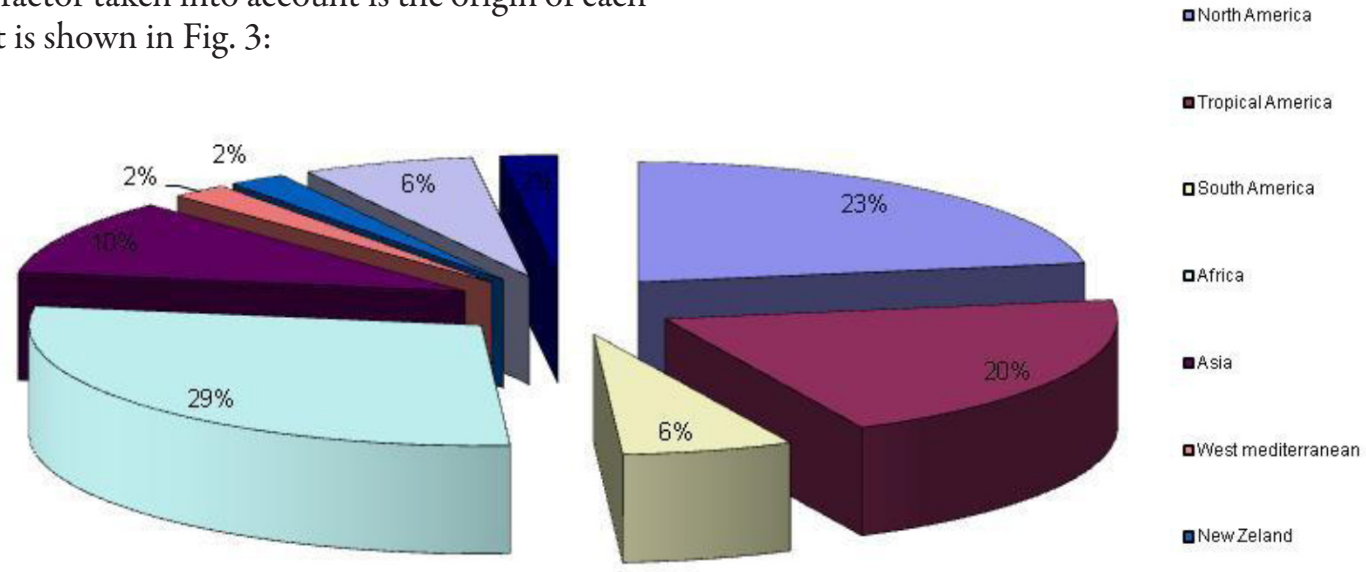

Fig. 3. Invasive species origin 


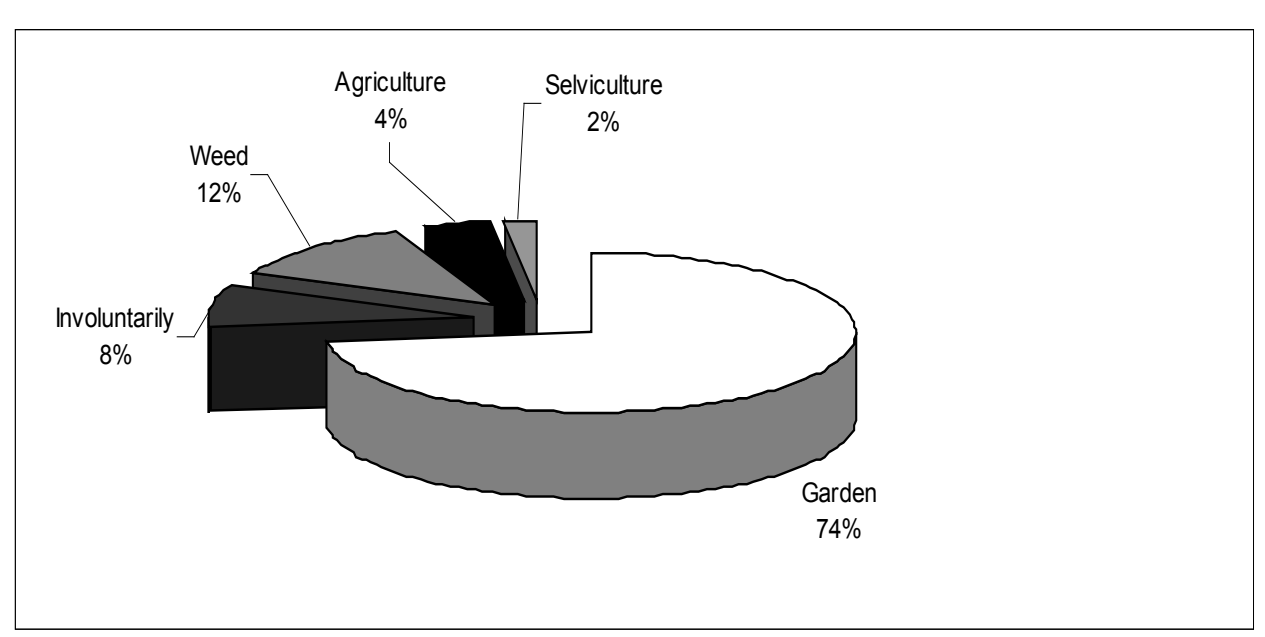

Fig. 4. Mode of introduction

species with a tropical origin. This shows the great ability of our country to host thermophilous species.

To find the causes of the presence of invasive species a study of its mode of introduction has been made, reaching the following results:

Gardening is de most important way of introduction ( $76 \%$ of introduced species) of ornamental species that escaped from culture and became naturalised, with more or less success. This is due mainly to the development of gardening based almost exclusively on the use of exotic elements instead of using autochthonous species, much more advisable, as the native flora is well adapted to our environmental conditions and includes taxa with ornamental potential as well. (Sanz Elorza et al., 2004).

On the other hand, introductions made by chance increased due to the development of trade and tourism in recent years.

3. Relation between invasive species and autochthonous plant communities

It is important to know the concentration or abundance in which we can find the invasive species and their growing area approximately. The locations of the most representative species have been mapped and the surface which they occupy was calculated. Also it has been proved that native plant communities were invaded by the species. The monitoring was carried out in communities considered autochthonous, since most of their species are native. The results are shown in the following table:

Species that are able to colonize plant communities of different ecosystems present in this zone are:

Carpobrotus edulis

Agave spp.

Arundo donax

Yucca spp.

Nicotiana glauca

Opuntia spp.

Cortaderia selloana

Furthermore, the associations that present higher number of invasive species are:
Centaureo maritimae-Echietum sabulicolae

Medicagini marinae-Ammophiletum australis

Asphodelo fistulosi-Hordeetum leporini

Cypero mucronati-Agropyretum juncei

Parapholido incurvae-Catapodietum marini

The abundance of Carpobrotus edulis, coming to occupy nearly $30,000 \mathrm{~m}^{2}(46 \%)$ and dispersed throughout the study area. In the same situation is Arundo donax, which occupies almost $23,000 \mathrm{~m}^{2}(36 \%)$. In this second case Arundo donax was found further away to the mainland, but Carpobrotus edulis is covering the dunes themselves, causing serious issue on vegetation.

Carpobrotus edulis in many cases is accompanied by other invasive species as Yucca gloriosa $\left(2000 \mathrm{~m}^{2}\right)$ and Agave spp. (11\% of land area covered by invasive species).

With the species represented in the chart above, the total $63,961 \mathrm{~m}^{2}$ area occupied by invasive species. This measure may change due to their rapid proliferation.

\section{Conclusions}

The potential natural vegetation has decreased its distribution area, which has modified its syntaxonomic composition with an increase in ruderal and weed communities, so that 38 of the present asociations, 14 of them are weedy and greens communities. The results shows that onvasive species are able to penetrate, both in the vegetal coastal communities and the nitrophile communities that substitute them. Of the total surface of the study area $4 \%$ is covered by invasive species. This is an considerable invasion level, seeing that the dunes communities have few vegetal coberture. Moreover, it has an strong landscape impact. It is not simply particular biological characteristics that determines invasiveness (Kueffer et al., 2010). The paper of the human being as propagator element is very important, like in other parts of the world (Trueman et al., 2010).

However, the presence of 14 habitats from the Habitats Directive proves the high ecologic value that the area 
has. For the conservation and recovery is prioritary the invasive plants eradication (specially the Carpobrotus, Yucca, Agave, Opuntia y Cortaderia genus), and the control of populations of Arundo donax, with the land use ordenation, in order to prevent the vegetation trampling and soil degradation.

\section{Acknowledgements}

This study is part of a project to study the coast by the UPV and directed by Jose Serra, has been sponsored by government institutions (General Directorate of Coasts, Ministry of Environment ("Ministerio de Medio Ambiente y Medio Rural y Marino") and Wildlife Service of Valencia Regional Government (Generalitat Valenciana, the Local Government of the Valencian region). We thank Juan Gimenez and Javier Ranz, the servicing of your support for this project.

\section{References}

Bartolomé C, Álvarez Jiménez J, Vaquero J (2005). Habitat types of community interest in Spain. Ministerio de Medio Ambiente: Dirección General para la Biodiversidad. Natura 2000 (in Spanish).

Braun-Blanquet J (1979). Phytosociology. Bases for the study of plant Communities, Ed. Blume. Barcelona (in Spanish).

Cáceres JM (2007). Spanish ornamental flora. Consejería de Agricultura y Pesca, Junta de Andalucía. Ediciones MundiPrensa. Asociación Española de Parques y Jardines Públicos.

Castroviejo S et al. (Ed.) (1986-2010). Iberian Flora (in Spanish). Real Jardín Botánico. Madrid.

Chamarro I, Silveira R, Donat MP Mayoral O (2010). Study of Invasive Plants of Marjal Xeresa (Province of Valencia, Comunidad Valenciana). In: GEIB group specializing in Biological Invasions (Ed.). Biological invasions: Progress 2009. 3rd Proceedings of the National Congress on Biological Invasions "EEI 2009" Technical Series 4:89 (in Spanish).

Costa M (1999). The vegetation and landscape in the Valencian land (in Spanish). Ed. Rueda. 342 pp.

European Commission (2007). Interpretation Manual of European Union Habitats-EUR27. DG. Environment.

Ferrer F (2008). Study the current state of the coastal vegetation between the mouth of the River Jucar Racons (Valencia, Spain) (in Spanish). Universidad Politécnica de Valencia.

Kueffer C, Daehler CC, Torres-Santana CW, Lavergne C, Meyer J, Otto R, Silva L (2010) A global comparison of plant invasions on oceanic islands. Perspect Plant Ecol Evol Syst 12:145-161.
López Lillo A, Trigo Pérez MM, Argimon de Vilardaga X, Sánchez De Lorenzo Lourbe C, Donat MP (2005). Programme for the spreading of the reinforcement strategies of the autochthonous flora in front of the threat represented by invading plants in the coastal region of Xeraco (Valencia, Spain). Environmental Encounters Series 59:351.

Mateo G, Crespo MB (2009). Handbook for identification of Valencian flora. $4^{\text {th }}$ ed. Valencia (in Spanish).

Raunkjaer S (1934). The life forms of plants and statistical plant geography. Oxford University Press. United Kingdom.

Rivas-Martínez S, Díaz TE, Fernánez-González F, Izco J, Loidi J, Lousã M, Penas A (2002). Vascular plant comunities of Spain and Portugal. Itinera Geobot 15(1-2):5-922.

Rivas-Martínez S (2007). Map series, geoseries and vegetation geopermaseries Spain. Memory of the potential vegetation map of Spain. Part 1. Itinera Geobot 17:1-222 (in Spanish).

Rivas-Martínez S, Fernández-Gonzalez F, Loidi F, Lousã M, Penas A (2001). Syntaxonomical Checklist of vascular plants communities of Spain and Portugal to association level. Itinera Geobot 14.

Rivas-Martínez, S (2008). Global Bioclimatics. www. globalbioclimatics.org.

Sanz Elorza M, Dana Sánchez ED, Sobrino Vesperinas E (2004). Atlas of Invasive Alien Plants in Spain. Dirección General para la Biodiversidad. Madrid (in Spanish).

Silveira R, Chamarro I, Mayoral O, Donat MP (2010). Study of exotic vascular flora of the Marsh of Gandía (Valencia). In: GEIB group specializing in Biological Invasions (Ed.). Biological Invasions: Progress 2009. $3^{\text {rd }}$ Proceedings of the National Congress on Biological Invasions "EEI 2009" Technical Series 4:89 (in Spanish).

Soriano P (1995). Study of vegetation and flora of the region of La Safor (Valencia) (in Spanish). Doctoral Thesis. Universidad de Valencia.

Trueman M, Atkinson R, Guezou A, Wurm P (2010). Residence time and human-mediated propagule pressure at work in the alien flora of Galapagos. Biol Invasions 12:3949-3960.

Tutin TG, Burges NA, Chater AO, Heywood VH, Moore DM, Valentine DH, Walters SM, Webb DA (2002). Flora europaea. Vol. I. $2^{\text {nd }}$ ed. Cambridge Univ. Press.

Tutin TG, Heywood VH, Burges NA, Valentine DH, W Alters SM, Webb DA (1964-1980). Flora Europaea. Cambridge Univ. Press.

Vilá M, Valladares F, Traveset A, Santamaría L, Castro P (Coord.) (2008). Biological Invasions (in Spanish). CSIC. Cyan, Proyectos y Producciones Editoriales, S.A. Madrid. 